\title{
Evaluation of the permeability of the furcation area of deciduous molars conditioned with Er:YAG laser and cyanoacrylate
}

\section{Avaliação da permeabilidade da região da furca de molares decíduos condicionada com laser de Er:YAG e cianoacrilatos}

\author{
Adriene Mara Souza Lopes-Silva* \\ José Luiz Lage-Marques**
}

\begin{abstract}
The purpose of this study was to evaluate in vitro the dentin permeability of the deciduous pulp chamber floor after employing 2-octyl cyanoacrylate and Er:YAG laser. Twenty four deciduous molars were used, divided into four groups. After chemical-surgical preparation each group received a different treatment: Group 1 - control, without treatment; Group 2 - the floor of the pulp chamber was covered with a fine layer of 2-octyl cyanoacrylate; Group 3 - the floor of the pulp chamber was irradiated with Er:YAG laser $(250 \mathrm{~mJ}, 10 \mathrm{~Hz}$ for 30 seconds, $80 \mathrm{~J}$ of energy and 320 pulses), and covered with a fine layer of 2-octyl cyanoacrylate; and Group 4 - the floor of the pulp chamber was irradiated with Er:YAG laser set at the parameters already described. After that the specimens received application of $0.5 \%$ methylene blue, for 15 minutes. The teeth were cut, photographed, and the digitalized images were analyzed using the ImageLab program. The results obtained were submitted to statistical analysis. Group 4 (Er:YAG) presented the largest averages in percentage of dye penetration area (19.5\%), followed by Group 1 (11.1\%), Group 3 (1.4\%) and Group 2 $(0.2 \%)$. The experimental model allowed to conclude that the specimens conditioned with 2-octyl cyanoacrylate (Group 2) and Er:YAG laser associated to 2-octyl cyanoacrylate (Group 3) presented a decrease in permeability, and the specimens treated with Er:YAG laser (Group 4) presented an increase in permeability of the analyzed area.
\end{abstract}

DESCRIPTORS: Deciduous, tooth; Lasers; Cyanoacrylates; Dentin permeability.

\begin{abstract}
RESUMO: A proposta do presente experimento foi avaliar in vitro a permeabilidade da dentina no assoalho da câmara pulpar de dentes decíduos com o emprego do 2-octil cianoacrilato e laser de Er:YAG. Foram empregados 24 molares decíduos, divididos em quatro grupos. Após preparo químico-cirúrgico, cada grupo recebeu um tratamento diferente: Grupo 1 - controle, sem tratamento; Grupo 2 - o assoalho da câmara pulpar foi coberto com uma fina camada de 2-octil cianoacrilato; Grupo 3 - o assoalho da câmara pulpar foi irradiado com laser de Er:YAG $(250 \mathrm{~mJ}, 10 \mathrm{~Hz}$ por 30 segundos, energia total de $80 \mathrm{~J}$ e 320 pulsos), e coberto com uma fina camada de 2-octil cianoacrilato; e Grupo 4 - o assoalho da câmara pulpar foi irradiado com laser de Er:YAG, nos parâmetros já descritos. Em seguida, os espécimes receberam aplicação do corante azul de metileno a 0,5\%, por 15 minutos. Todos os espécimes foram cortados no sentido mésio-distal, foi realizada a leitura das imagens digitalizadas no programa ImageLab e os resultados obtidos foram submetidos à análise estatística. As amostras do Grupo 4 (Er:YAG) apresentaram as maiores médias em porcentagem de área corada (19,5\%), seguidas das do Grupo $1(11,1 \%)$, Grupo $3(1,4 \%)$ e Grupo $2(0,2 \%)$, respectivamente. O modelo experimental empregado permitiu concluir que os espécimes condicionados com 2-octil cianoacrilato (Grupo 2) e laser de Er:YAG associado ao 2-octil cianoacrilato (Grupo 3) apresentaram redução da permeabilidade, e os espécimes tratados com laser de Er:YAG (Grupo 4) apresentaram aumento da permeabilidade da área analisada.
\end{abstract}

DESCRITORES: Dente decíduo; Lasers; Cianoacrilatos; Permeabilidade da dentina.

\section{INTRODUCTION}

The intrinsic permeability of dentin is responsible for permitting bacterial or chemical substances to diffuse across dentin and irritate pulpal and periradicular tissues ${ }^{4}$. Success in endodontic therapy is based on a thorough knowledge of the root canal system and its periodontal communications. Reddy, $\mathrm{Babu}^{14}$ (1993) showed a greater prevalence of accessory canals in the furcation and furcation region of primary molars. Wrbas et al. ${ }^{18}$ (1997) concluded that accessory furcation canals might be responsible for interadicular bone alterations of primary molars in case of pulpal inflammation or necrosis.

Measurements of the alteration of dentin permeability resulting from laser exposure have been made using a variety of methods. Miserendino et al. ${ }^{8}$ (1995) evaluated the effects of Nd:YAG laser irradiation by scanning electron microscope and dye

${ }^{*}$ PhD, Professor of Pediatric Dentistry, Department of Dentistry, University of Taubaté.

**Associate Professor, Department of Endodontics, School of Dentistry, University of São Paulo. 
Lopes-Silva AMS, Lage-Marques JL. Evaluation of the permeability of the furcation area of deciduous molars conditioned with Er:YAG laser and cyanoacrylate. Pesqui Odontol Bras 2003;17(3):212-6.

penetration. They reported a sealing of the dentinal wall by deposition of glass-like material. Lage-Marques et al. ${ }^{6}$ (1995) demonstrated the morphological changes that take place on root canal walls lased with pulsed Nd:YAG laser. The debris and the smear layer are removed and the lased dentin tubules are melted and closed. Tokonabe et al. ${ }^{17}$ (1999) investigated morphological changes in human enamel and dentin structures irradiated with the use of an Er:YAG laser. The lased area showed a clean-cut margin in dentin, no smear layer was present at the bottom of the irradiated area, and the openings of the dentinal tubes were clear.

Application of cyanoacrylate for reduction of dentin permeability has been reported by Lage-Marques et al. ${ }^{5}$ (1992). They observed that the samples submitted to treatment with Histoacryl over the floor of the pulp chamber and around the marginal-cervical sealing of the canal filling did not show any leakage of the 1\% Rhodamine B dye. It has been observed that cyanoacrylate has antimicrobial activity ${ }^{11}$.

The purpose of this study was to evaluate in vitro the dentin permeability of the deciduous pulp chamber floor after employing 2-octyl cyanoacrylate and Er:YAG laser.

\section{MATERIALS AND METHODS}

The Committee of Ethics in Research, University of Taubaté, approved the present experiment (Protocol 076/2000).

Twenty four extracted human deciduous molars were obtained from the teeth bank of the Endodontics Discipline. The teeth were treated according to the Guedes-Pinto ${ }^{2}$ (1993) technique for endodontic treatment of deciduous teeth with pulp necrosis. The teeth were mounted on an acrylic stand in order to maintain them in a resting position. After that, the specimens were randomly divided into four groups, and each group received a different treatment: Group 1 - control, without treatment; Group 2 - the floor of the pulp chamber was covered with a fine layer of 2-octyl cyanoacrylate; Group 3 - the floor of the pulp chamber was irradiated with Er:YAG laser $(250 \mathrm{~mJ}, 10 \mathrm{~Hz}$ for 30 seconds, $80 \mathrm{~J}$ of energy and 320 pulses), and covered with a fine layer of 2-octyl cyanoacrylate; and Group 4 - the floor of the pulp chamber was irradiated with Er:YAG laser set at the parameters already described.

\section{2-octyl cyanoacrylate}

Dermabond (Johnson \& Johnson Co., São José dos Campos, Brazil) is a sterile, liquid topical skin adhesive containing a monomeric (2-octyl cyanoacrylate) formulation and the colorant D\&C Violet \#2. It is provided in a single use applicator packaged in a blister pouch. When applied, the liquid adhesive is slightly more viscous than water and polymerizes within minutes. A thin layer of Dermabond was applied on the pulp chamber floor.

\section{Laser treatment}

The laser used in this study was Er:YAG (Kavo Key Laser, Kavo, Germany), with wavelength of $2.94 \mu \mathrm{m}$ and pulse duration of $500 \mathrm{~ms}$, using refrigeration with distilled water and air. It was applied with a periodontal tip (rectangular form, $1.6 \times 0.5 \mathrm{~mm}$ ) on the pulp chamber floor, covering the whole furcation. The Er:YAG laser was applied at the following parameters: $250 \mathrm{~mJ}, 10 \mathrm{~Hz}$, for 30 seconds, total energy of $80 \mathrm{~J}$ and 320 pulses.

\section{Dye penetration}

After treatment the entrances of the root canals were sealed with gutta percha and covered with a fine layer of cyanoacrylate. Then, the pulp chamber was filled with $0.5 \%$ aqueous solution of methylene blue (Manipulario manipulation pharmacia, Taubaté, Brazil) for 15 minutes. The teeth were then washed in running water, and longitudinally sectioned in a mesiodistal direction.

After that, the specimens were photographed in the same conditions and the images were analyzed using the ImageLab program (software developed by LIDO - Computer Science Laboratory Dedicated to Dentistry, University of São Paulo, São Paulo, Brazil). The percentage of the colored area by dye penetration was measured.

\section{Statistical analysis}

The means of the percentage of colored area for the four test groups were subjected to the Kruskal-Wallis test at a significance level of $p>0.01$.

\section{RESULTS}

The results showed that 2-octyl cyanoacrylate was the most effective to control the permeability of the pulp chamber floor. Graph 1 allows to observe the largest effectiveness of the treatment in Group 2 (2-octyl cyanoacrylate) followed by Group 3 (Er:YAG laser + 2-octyl cyanoacrylate), Group 1 (control) and Group 4 (Er:YAG laser). 
Lopes-Silva AMS, Lage-Marques JL. Evaluation of the permeability of the furcation area of deciduous molars conditioned with Er:YAG laser and cyanoacrylate. Pesqui Odontol Bras 2003;17(3):212-6.

The statistical analyses are presented in Table 1 and 2 . There were significant differences between the groups: Group 1 (control) and Group 2 (2-octyl cyanoacrylate); Group 1 (control) and Group 3 (Er:YAG laser + 2-octyl cyanoacrylate); Group 2 (2-octyl cyanoacrylate) and Group 4 (Er:YAG laser); Group 3 (Er:YAG laser + 2-octyl cyanoacrylate) and Group 4 (Er:YAG laser). There were no significant statistical differences between Group 2 and Group 3; and between Group 1 (control) and Group 4 (Er:YAG laser).

\section{DISCUSSION}

The furcation area of a molar tooth, which encompasses the region around the division of roots, is of special significance in the primary dentition due to its close anatomical relationship with the follicle of the permanent molar successor ${ }^{9,15}$.

The intrinsic permeability of the furcation may be responsible for interradicular bone alterations of primary molars in case of pulpal inflammation or necrosis ${ }^{2,18}$. Accessory canals in the furcation area are clinically important for several reasons.

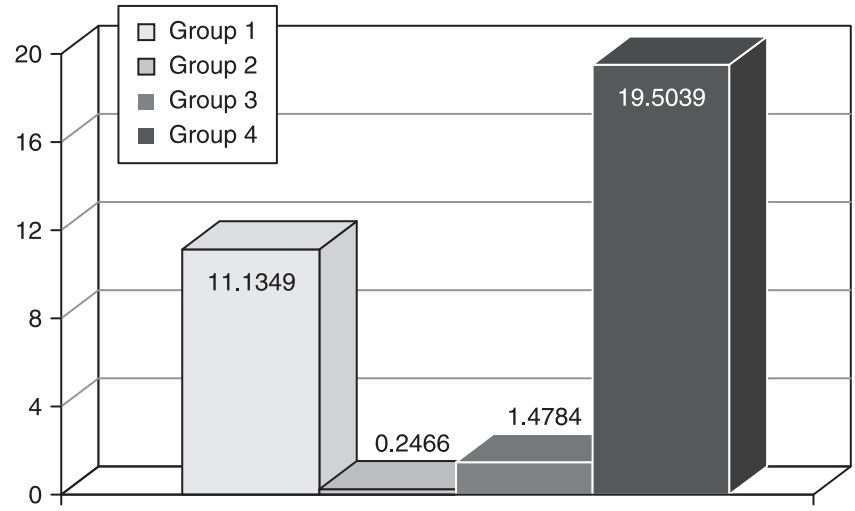

GRAPH 1 - Distribution of the mean values of the results in percentage of the colored area, in the different experimental groups.
Infections stemming in the pulp can spread through the furcation foramina to affect the interradicular bone ${ }^{9}$; in addition, medicaments placed in the pulp can enter furcation bone through these canals ${ }^{18}$.

The presence of accessory canals in the furcation of primary molars has been investigated. Ringelstein, Seow ${ }^{15}$ (1989) examined 75 deciduous molars using dye penetration, demonstrating that $42.7 \%$ have foramina located within the furcation region; Reddy, Babu ${ }^{14}$ (1993) revealed the presence of accessory canals in 30\% of 120 deciduous molars; Wrbas et al. ${ }^{18}$ (1997) observed that accessory foramina were present in the furcation of 16 out of 20 teeth (80\%), in all cases of accessory orifices found in the furcation area. The authors showed the high prevalence of accessory canals in the furcation region of primary molars, and suggest that communications of the pulp with interradicular bone and periodontal tissues are highly possible. The present study showed a greater permeability of the pulp chamber floor of deciduous teeth, in that dye penetration was present in the specimens of all groups.

The use of a material capable of sealing the pulp chamber floor, eliminating microorganisms and the invasion of inflammatory fluids through accessory canals, after cleaning and filling of the root canals, would be the ideal solution to prevent endodontic treatment failure.

TABLE 1 - Results of the Kruskal-Wallis test: original values.

\begin{tabular}{l|c}
\hline \hline Value $(\mathrm{H})$ calculated of Kruskal-Wallis & 12.9615 \\
\hline Value for $\chi^{2}$ to 3 freedom degrees & 12.96 \\
\hline Probability of $\mathrm{H}_{0}$ for this value & $0.47 \%$ \\
\hline \hline
\end{tabular}

Significance at the level of $1 \%(\alpha=0.01) \cdot \chi^{2}=$ chi-square test.

TABLE 2 - Results of the Kruskal-Wallis test: original values. Comparison between averages of the positions of the samples.

\begin{tabular}{c|c|c|c|c|c}
\hline \hline \multirow{2}{*}{$\begin{array}{c}\text { Compared samples } \\
\text { (pair comparisons) }\end{array}$} & \multirow{2}{*}{$\begin{array}{c}\text { Differences between } \\
\text { averages }\end{array}$} & \multicolumn{3}{|c}{ Critical values $(\alpha)$} & \multirow{2}{*}{ Significance $(\alpha)$} \\
\cline { 3 - 6 } & 11.0833 & 5.8129 & 7.9280 & 10.7285 & $0.1 \%$ \\
\hline Group 1 versus Group 2 & 9.1667 & 5.8129 & 7.9280 & 10.7285 & $1 \%$ \\
\hline Group 1 versus Group 3 & 0.4167 & 5.8129 & 7.9280 & 10.7285 & $\mathrm{~ns}$ \\
\hline Group 1 versus Group 4 & 1.9167 & 5.8129 & 7.9280 & 10.7285 & $\mathrm{~ns}$ \\
\hline Group 2 versus Group 3 & 10.6667 & 5.8129 & 7.9280 & 10.7285 & $1 \%$ \\
\hline Group 2 versus Group 4 & 8.7500 & 5.8129 & 7.9280 & 10.7285 & $1 \%$ \\
\hline Group 3 versus Group 4 & & & & \\
\hline \hline
\end{tabular}

$\mathrm{ns}=$ not significant. 
Lopes-Silva AMS, Lage-Marques JL. Evaluation of the permeability of the furcation area of deciduous molars conditioned with Er:YAG laser and cyanoacrylate. Pesqui Odontol Bras 2003;17(3):212-6.

A group of adhesives called cyanoacrylates were first described in 1949. They polymerize in an exothermic reaction upon contact with a fluid or basic substance, forming a strong bond ${ }^{12}$. Prior studies have shown that butyl-2-cyanoacrylate's impermeability capacity, even in the presence of humidity ${ }^{5}$, provides antimicrobial properties to the material ${ }^{1,11,13}$ and thus favors its use in dentistry. Lage-Marques et al. ${ }^{5}$ (1992) showed that Hystoacryl (butyl-2-cyanoacrylate) controls microleakage of oral fluids at the filling/tooth interface. Our results also confirmed the Dermabond's (2-octyl cyanoacrylate) capacity to reduce pulp chamber floor permeability (Group 2).

The use of Er:YAG laser for endodontic purposes has produced very effective preparations of root canals ${ }^{7}$, with minimal thermal damage to surrounding tissues ${ }^{17}$. Previous studies have evaluated the effects of Er:YAG laser irradiation on dentin surfaces. Takeda et al. ${ }^{16}$ (1999) irradiated the root canal wall with Er:YAG laser, and revealed clean surfaces, free of smear layer, with open dentinal tubules without any melting. A study ${ }^{16}$ revealed that the Er:YAG laser has a structural effect on human teeth similar to that of etching with acid. Kawabata et al. ${ }^{3}$ (1999) irradiated the human enamel and dentin with Er:YAG laser and observed that application of this laser did not induce carbonization or cracking, and it was unable to seal the dentinal tubule. Takeda et $a .^{16}$ (1999) reported that Er:YAG laser was effective to clean the root canal because it increases dentin permeability. The present study is in accordance with these findings, as Group 4 (Er:YAG laser) presented a high mean of dye penetration when compared with the other groups.

\section{REFERENCES}

1. Eiferman RA, Snyder JN. Antibacterial effect of cyanoacrylate glue. Arch Ophthalmol 1983;101:958-60.

2. Guedes-Pinto AC. Tratamento endodôntico em dentes decíduos. In: Guedes-Pinto AC. Odontopediatria. $4^{\text {a }}$ ed. São Paulo: Santos; 1993. p. 661-87.

3. Kawabata A, Kawabata H, Yagasaki A, Iwasaki H, Miyazawa $\mathrm{H}$. Effects of laser irradiation on dentin: in vitro morphological study following application of various types of lasers. Pediatr Dent J 1999;9:83-9.

4. Koutsi V, Noonan RG, Horner JA, Simpson MD, Matthews WG, Pashley DH. The effect of dentin depth on the permeability and ultrastructure of primary molars. Pediatr Dent 1994;16:29-35.

5. Lage-Marques JL, Conti R, Antoniazzi JH. The use of Histoacryl in endodontics. Braz Dent J 1992;3:95-8.
The properties of cyanoacrylate and Er:YAG laser irradiation might have allowed good penetration of Dermabond in Group 3 specimens, decreasing permeability. This result is in agreement with those of Pecora et al. ${ }^{10}$ (2000), who showed that the increase in dentin permeability produced by Er:YAG laser irradiation represents more open tubules, which are important for mechanical adhesion to occur between the root canal sealer and dentin.

These results suggested that 2-octyl cyanoacrylate could be applied with advantages on the pulp chamber floor of deciduous teeth with pulp necrosis, but further in vivo studies are needed before clinical use can be recommended.

\section{CONCLUSIONS}

The experimental model of the present study allowed us to conclude that:

- The specimens of the four groups presented dye penetration, thus confirming the permeability of the treated area.

- Octyl-2-cyanoacrylate (Group 2) and Er:YAG laser associated with octyl-2-cyanoacrylate (Group 3) reduced the permeability of the treated area with significant statistical differences when compared with the other groups.

- Er:YAG laser irradiation (Group 4) increased the permeability of the pulp chamber floor of deciduous molars.

\section{ACKNOWLEDGMENT}

This study was supported by the Experimental Laboratory of Laser in Dentistry (LELO - Laboratório Experimental de Laser em Odontologia), School of Dentistry, University of São Paulo, Brazil.

6. Lage-Marques JL, Eduardo CP, Matsumoto K. A study on morphological changes of the root canal wall lased by pulsed Nd:YAG laser. J Japan Endod Assoc 1995;16:64-9.

7. Mehl A, Folwaczny M, Haffner C, Hickel R. Bactericidal effects of $2.94 \mu \mathrm{m}$ Er:YAG-laser radiation in dental root canals. J Endod 1999;25:490-3.

8. Miserendino J, Levy GC, Rizoiu IM. Effects of Nd:YAG laser on the permeability of root canal wall dentin. J Endod 1995;21:83-7.

9. Myers DR, Battenhouse MR, Barenie JT, Singh B. Histopatology of furcation lesions associated with pulp degeneration in primary molars. Pediatr Dent 1987;9:279-82.

10. Pécora JD, Brugnera-Junior A, Cussioli AL, Zanin F, Silva R. Evaluation of dentin root canal permeability after ins- 
Lopes-Silva AMS, Lage-Marques JL. Evaluation of the permeability of the furcation area of deciduous molars conditioned with Er:YAG laser and cyanoacrylate. Pesqui Odontol Bras 2003;17(3):212-6.

trumentation and Er:YAG laser application. Lasers Surg Med 2000;26:277-81.

11. Quinn JV, Osmond MH, Yurack JA, Moir PJ. N-2-butylcyanoacrylate: risk of bacterial contamination with an appraisal of its antimicrobial effects. $J$ Emerg Med 1995;13:581-5.

12. Quinn J, Wells G, Sutcliffe T, Jarmuske M, Maw J, Stiell I, et al. A randomized trial comparing octylcyanoacrylate tissue adhesive and sutures in the management of lacerations. J Am Med Assoc 1997;277:1527-30.

13. Quinn J, Maw J, Ramotar K, Wenckeback G, Wells G. Octylcyanoacrylate tissue adhesive versus suture wound repair in a contaminated wound model. Surgery 1997;122:69-72.

14. Reddy VV, Babu S. Prevalence location and patency of accessory canals in primary molars using dye penetration under vacuum suction technique: an in vitro study. J Indian Soc Pedod Prev Dent 1993;11:28-32.

15. Ringelstein D, Seow WK. The prevalence of furcation foramina in primary molars. Pediatr Dent 1989;11:198-202.

16. Takeda FH, Harashima T, Kimura Y, Matsumoto K. A comparative study of the removal of smear layer by three endodontic irrigants and two types of laser. Int Endod $\mathrm{J}$ 1999;32:32-9.

17. Tokonabe H, Kouji R, Watanabe H, Nakamura Y, Matsumoto K. Morphological changes of human teeth with Er:YAG laser irradiation. J Clin Laser Med Surg 1999; 17:7-12.

18. Wrbas KT, Kielbassa AM, Hellwig E. Microscopic studies of accessory canals in primary molar furcations. ASDC $\mathrm{J}$ Dent Child 1997;64:118-22.

Recebido para publicação em 17/12/02

Enviado para reformulação em 28/05/03

Aceito para publicação em 24/06/03 